\title{
A Plea for Legal Peace
}

\author{
Riccardo Pavoni
}

\begin{abstract}
This chapter advocates legal peace between Germany and Italy as the most sensible and appropriate way to deal with the aftermath of Sentenza 238/2014 of the Italian Constitutional Court and its declaration of the unconstitutionality of the 2012 International Court of Justice (ICJ) Judgment in Jurisdictional Immunities. This plea does not only arise from frustration with the current impasse but also from the suspicion that the public good of legal peace has never seriously been canvassed by the Italian and German governments. Section II takes stock of the legal developments relating to the dispute between Germany and Italy since Sentenza 238/2014 was delivered. It especially focuses on the attitudes of the governments concerned, both in the context of the ongoing proceedings before Italian courts and elsewhere. It finds such attitudes opaque and unduly dismissive of the necessity to devise legal peace in the interest of the victims and of the integrity of international law. Section III highlights how the behaviour of the governments so far was at odds with the successful outcome of other intergovernmental negotiations concerning reparations for crimes committed during World War II (WWII), a process which has not been entirely finalized, as evidenced by the 2014 Agreement between the US and France on compensation for the French railroad deportees who were excluded from prior French reparation programmes. The Agreement between the US and France and all previous similar arrangements were concluded under mounting pressure of litigation before domestic courts against those states (and/or their companies) that were responsible for unredressed WWII crimes, thus a situation resembling the current state of the dispute between Germany and Italy. It is telling that litigation ended when the courts took cognizance of the stipulation of intergovernmental agreements establishing fair mechanisms for compensating the plaintiffs and victims of the relevant crimes. Such practice, therefore, is essentially in line with the proposition that state immunity (for human rights violations) is essentially conditional on effective alternative remedies for the victims. This and other controversial aspects related to the law of state immunity-such as the nature of state
\end{abstract}

\footnotetext{
R. Pavoni $(\bowtie)$

University of Siena, Department of Law, Siena, Italy

e-mail: riccardo.pavoni@unisi.it 
immunity, the North American remedies against immunity for state sponsors of terrorism, and the persistent dynamism of pertinent practice-are revisited in section IV. The purpose is to suggest that certainty about the law of international immunities, as allegedly flowing from the 2012 ICJ Judgment, is more apparent than real and that this consideration should a fortiori urge the realization of legal peace in the German-Italian affair.

\section{Introduction}

This chapter argues that 'legal peace' between Germany and Italy is the most sensible and appropriate way of dealing with the aftermath of Sentenza 238/2014 of the Italian Constitutional Court (ItCC), ${ }^{1}$ which in substance held that the 2012 International Court of Justice (ICJ) Judgment in Jurisdictional Immunities ${ }^{2}$ could not be given effect as it breached the human right to judicial protection under the Italian Constitution. The ItCC also refused to afford any domestic legal effects to the ICJ-backed rule of state immunity for unredressed international crimes. Although such a plea for legal peace arises, in part, from the frustrating impasse that presently characterizes the dispute between Germany and Italy, it is especially driven by the disturbing impression that, in the context of unredressed World War II (WWII) crimes, the public good of legal peace has never been canvassed seriously by either the Italian or German government.

Admittedly, there is no silver bullet for shaping legal peace against the background of the German-Italian affair. Legal peace might well be channelled through arbitration, thereby conclusively determining whether Germany or Italy, or both, have defaulted with respect to compensation owed to Italian Military Internees (IMIs) and similarly situated victims of Nazi crimes. In any event, the crucial step would be the elaboration of a fair institutional and exclusive funding mechanism entrusted with processing outstanding compensation claims. While foreclosing parallel private litigation, this mechanism should be capable of giving victims a voice. The lack of an effective remedy for the victims, other than judicial proceedings in Italy, was indeed a key consideration underlying Sentenza 238/2014. ${ }^{3}$ There are sound reasons for believing that the setting up of a meaningful compensatory procedure would lead to the suspension or termination of the remaining cases pending against Germany before Italian courts. ${ }^{4}$

\footnotetext{
${ }^{1}$ Corte Costituzionale, Judgment of 22 October 2014, No 238/2014.

${ }^{2} \mathrm{ICJ}$, Jurisdictional Immunities of the State (Germany $v$ Italy: Greece intervening), Judgment of 3 February 2012, ICJ Reports 2012, 99.

${ }^{3}$ See Riccardo Pavoni, 'How Broad is the Principle Upheld by the Italian Constitutional Court in Judgment No. 238?', Journal of International Criminal Justice 14 (2016), 573-585.

${ }^{4}$ For instance, the Tribunal of Sulmona has recently awarded damages in the amount of $€ 6.6$ million against Germany and in favour of the heirs of victims of a WWII massacre in the Abruzzo region and of the Municipality of Roccaraso. See Tribunale di Sulmona, Judgment of 2 November 2017,
} 
Section II takes stock of the legal developments in the German-Italian affair since Sentenza 238/2014 was delivered. It focuses on the attitudes of the governments concerned within the proceedings before Italian courts and elsewhere. It finds these attitudes opaque and unduly dismissive of the necessity to promote legal peace in the interest of the victims and for the integrity of international law. Section III highlights how the behaviour of the two governments is at odds with the successful outcomes of other intergovernmental negotiations prompted by litigation before US courts relating to crimes committed during WWII, a process meaningfully started in the 1990s and still unfinished. Tellingly, litigation ended when the courts took cognizance of the stipulation of intergovernmental agreements establishing fair mechanisms for compensating victims, whereas the outstanding cases currently pending before US courts precisely involve situations that are not covered by such agreements. Such practice, therefore, is essentially in line with the proposition that state immunity (for human rights violations) should be conditional on effective alternative remedies for the victims. ${ }^{5}$ Accordingly, section IV underscores that a number of

Case No 20/2015, available at http://www.europeanrights.eu/public/sentenze/ITA-Tribunale_di_ Sulmona_strage_di_pietransieri_Sulmona.pdf; for a comment, see Ferdinando Franceschelli, 'Germany Held Responsible for the Nazi Massacre of Pietransieri', Italian Yearbook of International Law 27 (2017), 449-452.

Various enforcement proceedings are also ongoing. See lately, Corte di Cassazione, Judgment of 3 September 2019, No 21995/2019 (Deutsche Bahn v Sterea Ellada Region), allowing the continuation of garnishment proceedings against debts owed to Deutsche Bahn by the Italian railway company for the purpose of recovering the damages awarded to the victims (and their heirs) of the WWII Distomo massacre in Greece. However, in parallel proceedings relating to the same dispute, the Court of Cassation held that Villa Vigoni-real estate owned by Germany—enjoyed immunity from measures of constraint as it was exclusively used for sovereign, non-commercial purposes; see Corte di Cassazione, Judgment of 8 June 2018, No 14885/2018 (Sterea Ellada Region v Germany and Presidency of the Council of Ministers).

${ }^{5}$ Although with several variations and to different degrees, this view is regarded by a growing number of authors as the sole means of reconciling international and domestic law in this area, see, eg, Micaela Frulli, “"Time Will Tell Who Just Fell and Who's Left Behind": On the Clash between the International Court of Justice and the Italian Constitutional Court', Journal of International Criminal Justice 14 (2016), 587-594, at 589-592; Riccardo Pisillo Mazzeschi, 'Access to Justice in Constitutional and International Law: The Recent Judgment of the Italian Constitutional Court', Italian Yearbook of International Law 24 (2014), 7-23, at 18-20; Rosanne van Alebeek, 'Jurisdictional Immunities of the State (Germany $v$. Italy): On Right Outcomes and Wrong Terms', German Yearbook of International Law 55 (2012), 281-318, at 312 (although taking a very cautious view and, however, concluding that IMIs did have an effective remedy in Germany); Riccardo Pavoni, 'Human Rights and the Immunities of Foreign States and International Organizations', in Erika de Wet/Jure Vidmar (eds), Hierarchy in International Law: The Place of Human Rights (Oxford: OUP 2012), 71-113; Benedetto Conforti, 'The Judgment of the International Court of Justice on the Immunity of Foreign States: A Missed Opportunity', Italian Yearbook of International Law 21 (2011), 133-142, at 138-142 (largely foreshadowing the decision of the Constitutional Court discussed in the present book: '[I]mplementation [of international law] cannot be pushed to the point of compromising the fundamental values of the State community, usually guaranteed by constitutional rules (...). There is no doubt that the right of access to justice is part of such fundamental values (...), and that, consequently, a customary rule inconsistent with Article 24 [of the Italian Constitution] cannot be applied in Italy'). Other authors point out that the 
tensions and controversial issues continue to affect the doctrine of state immunity, starting from the unresolved question of its rationale and nature. The best illustration thereof is no doubt offered by the contemporary practice of Canada and the US. The ultimate purpose of section IV is to suggest that certainty about the law of international immunities, as allegedly flowing from the 2012 ICJ Judgment, is more apparent than real and that this consideration should a fortiori urge the realization of legal peace in the German-Italian affair. A few concluding remarks are made in section $\mathrm{V}$.

\section{Confrontation and Mutual Neglect Versus Legal Peace}

The conduct of the two governments concerned both prior to and in the aftermath of Sentenza 238/2014 has been characterized - to different degrees and with different modalities - by reticence, ambiguity, and underground talks. Paradigmatic of this conduct was the inaugural event in late 2016 of the permanent exhibition dedicated to IMIs in the Berlin-Schöneweide Lager, a rather well-preserved WWII concentration camp. On that occasion, speaking before a wide audience including representatives of IMIs associations, the German and Italian Foreign Ministers made absolutely no mention of the unresolved legal issues raised by the exclusion of IMIs from any meaningful WWII reparation scheme and the related litigation against Germany in Italian courts. ${ }^{6}$ After all, the two countries were smoothly proceeding along the direction set forth in their 2008 Trieste Joint Declaration, whence they announced the objective of creating a 'common culture of memory' regarding WWII (with a focus on the terrible vicissitudes of IMIs) and the establishment of an ItaloGerman Historical Commission for that purpose. There was apparently no link between the financing of the exhibition and the German-Italian dispute. It is clear, however, that the great absentees in that context were Italian judges and Sentenza $238 / 2014$.

Interestingly, a few days later the Chamber of Deputies of the Italian parliament—endorsed by the executive—passed a motion concerning WWII crimes

\footnotetext{
'alternative remedies test' also constitutes the sole means of reconciling international law with itself, see Giuseppe Cataldi, 'A Historic Decision of the Italian Constitutional Court on the Balance Between the Italian Legal Order's Fundamental Values and Customary International Law', Italian Yearbook of International Law 24 (2015), 37-52, at 46 ('When the fundamental principles of the national legal system guaranteed by the review of national supreme courts also correspond to the "common values" of the international community, these courts also act in the service of the international legal system. Essentially, in such cases, national courts protect international law from itself'). These authors evidently disapprove of the contrary conclusion reached by the ICJ in its Jurisdictional Immunities Judgment, when it flatly rejected the so-called last resort argument advanced by Italy; see ICJ, Jurisdictional Immunities (n 2), paras 101-103.

${ }^{6}$ Frank-Walter Steinmeier/Paolo Gentiloni/Michele Montagno, 'Zwischen allen Stühlen-die Geschichte der italienischen Militärinternierten 1943-1945', (28 November 2016), available at https://www.istitutocervi.it/wp-content/uploads/2017/02/Istituto-Cervi-a-Berlino.pdf.
} 
committed against Italian nationals, which indirectly allows us to understand the approach of the Italian government toward the WWII German reparations affair. ${ }^{7}$ The motion did not even mention Sentenza 238/2014, whereas it gave account of the 2012 ICJ Judgment and recalled that the latter 'unfortunately' ${ }^{\text {' upheld }}$ Germany's immunity before Italian courts. It committed the Italian government to make sure that Germany will continue to finance initiatives aimed at the reconstruction of a "shared historical memory"9 and 'moral reparation' ${ }^{10}$ for the victims of WWII crimes. The next steps, according to this motion, should therefore consist in having Germany renew its contribution to the German-Italian Fund for the Future (Fondo italo-tedesco per il futuro) for the years 2018-2021. This fund was jointly established in 2013 and operationalized thanks to an initial contribution by Germany to the amount of $€ 4$ million. These resources should be channelled into the construction or restoration of places of commemoration and comparable monuments, as well as into the development of memory-related online resources, such as an Atlas of the Nazi-Fascist massacres committed in Italy between 1943 and 1945 and a Biographic Lexicon of IMIs. ${ }^{11}$ Thus, the 2016 motion of the Italian parliament overlooked the many final judicial decisions awarding civil damages against Germany and diverted attention to the need for the government to secure German cooperation in the execution of criminal convictions of German nationals found responsible for Nazi crimes by Italian courts (which is a reference to the long-standing problem of the failed extradition of such nationals by Germany).

Therefore, several years after Sentenza 238/2014, the Italian government has yet to illustrate to its citizens its own official position on this decision, especially to those citizens most concerned: the plaintiffs and the judgment holders in the various pending or concluded proceedings relating to WWII Nazi crimes.

Clues about the Italian executive's position may emerge from a perusal of its legal arguments outlined before the Italian courts dealing or having dealt with WWII Nazi-related cases. But this is deeply unsatisfactory when seen against rule of law notions such as a government's responsiveness and transparency to its citizenry. While Sentenza 238/2014 may arguably be considered a 'shock to the international legal community', ${ }^{12}$ the Italian lay public are largely unaware of this judgment, despite its importance for Italian national history and for the evolution of Italian

\footnotetext{
${ }^{7}$ Chamber of Deputies of the Italian Parliament, Motion No 1-01375, adopted on 6 December 2016. ${ }^{8}$ Ibid (translated by the author).

${ }^{9}$ Ibid (translated by the author).

${ }^{10}$ Ibid (translated by the author).

${ }^{11}$ For an account of the genesis of this fund and a list of initiatives and projects that it has financed so far, see Rappresentanze tedesche in Italia, 'Cultura della memoria', available at https://italien.diplo. de/it-it/themen/kultur/CulturadellaMemoria-Ordner?openAccordionId=item-1599424\%2D\% 2Dpanel.

${ }^{12}$ Christian Tomuschat, 'The National Constitution Trumps International Law', Italian Journal of Public Law 6 (2014), 189-196, at 189 (emphasis added).
} 
sociological attitudes towards a tragic past which large sectors of the (older) population have never come to terms with. ${ }^{13}$

What is clear is that, regardless of their political inclination, the changing majorities leading the Italian government over the past decades have consistently pursued agendas that were decidedly at variance with the positions and parallel activities of the Italian judiciary. Soon after Sentenza 238/2014, the government surreptitiously took advantage of the parliamentary debates on the conversion into law of a decree containing a variety of measures on civil procedure in order to introduce an amendment making the attachment of any bank account held in Italy by foreign states in fact impossible. According to this provision, ${ }^{14}$ such bank accounts are not subject to execution provided that the head of a diplomatic mission or consular post of a foreign state has declared to the Italian Ministry of Foreign Affairs and the relevant bank that the money deposited therein is exclusively intended for use in the performance of diplomatic and/or consular functions. The foreign state's declaration triggers an absolute protection for such bank accounts, as it cannot be rebutted or challenged in court on any ground whatsoever. This is a very generous provision ${ }^{15}$ on foreign state bank account immunity, which goes beyond customary international law and Article 21(1)(a) of the UN Convention on Jurisdictional Immunities of States and Their Property (UNCSI). ${ }^{16}$ Arguably, by essentially obliterating the role of the judiciary in this matter, the provision is inconsistent with the Italian Constitution. ${ }^{17}$ However, the key point here is that, by hastily seeking solutions to the

\footnotetext{
${ }^{13}$ Even judges of the ItCC are not immune to this sociological dimension of WWII events and Nazi Germany's occupation of Italy from late 1943. Sabino Cassese, a member of the ItCC at the time of Sentenza 238/2014, nicely recalls how the deliberations on the case were oscillating between sophisticated reflections on the legal issues at stake and rhetorical recollections by certain judges who were evoking the 'Germans at their doorstep' ('Esercizi di ingegno, sottili domande giuridiche si alternano con esercizi di retorica di chi ricorda i tedeschi a casa propria'), Sabino Cassese, Dentro la Corte: Diario di un giudice costituzionale (Bologna: il Mulino 2015), 261.

${ }^{14}$ Art 19-bis of Italian Law-decree No 132 of 12 September 2014, converted by Law No 162 of 10 November 2014.

${ }^{15}$ For instance, compare Section 13(5) of the UK State Immunity Act (SIA), according to which the head of a foreign state's diplomatic mission is entitled to produce a certificate 'to the effect that any property is not in use or intended for use by or on behalf of the State for commercial purposes'; however, such a certificate 'shall be accepted as sufficient evidence of that fact unless the contrary is proved' (emphasis added) (SIA 1978, 17 ILM (1978) 1123). On the persistent key role of domestic courts in this specific area, see Chester Brown/Roger O'Keefe, 'Article 21', in Roger O'Keefe/ Christian J Tams (eds), The United Nations Convention on Jurisdictional Immunities of States and Their Property: A Commentary (Oxford: OUP 2013), 334-347, at 341-342, 347: 'It will probably remain the case, even in the application of Article 21(1), that one court's actum jure imperii is another's actum jure gestionis'.

${ }^{16}$ UN Convention on Jurisdictional Immunities of States and Their Property (2 December 2004), UN Doc A/RES/59/38, UN Doc A/59/49, 486 (not yet in force).

${ }^{17}$ Cf Corte Costituzionale, Judgment of 15 July 1992, No 329/1992 (Condor). For a fierce critique of the provision in question, see Benedetto Conforti, 'Il legislatore torna indietro di circa novant'anni: la nuova norma sull'esecuzione sui conti correnti di Stati stranieri', Rivista di diritto internazionale 98 (2015), 558-561.
} 
German-Italian contingencies, the Italian government runs the risk of turning a blind eye to opaque transactions and abuses facilitated by the privilege afforded to any foreign state bank accounts held in Italy. One should hope that the competent authorities will retain sufficient surveillance powers over such accounts.

Moreover, far from withdrawing from treaty provisions conferring jurisdiction on disputes involving Italy to international bodies, on 25 November 2014 the Italian government deposited its declaration of acceptance of the compulsory jurisdiction of the ICJ under Article 36(2) of the ICJ Statute. ${ }^{18}$ This course of action seems imprudent and untimely in the wake of Sentenza 238/2014, as the latter may spur domestic judicial proceedings against any foreign states accused of international crimes. ${ }^{19}$ Such proceedings may in turn be easily challenged before the ICJ on the strength of its 2012 Judgment. The Italian declaration contains no reservation to the ICJ jurisdiction relating to disputes in this area. The initiative of the Italian government in question also glaringly confirms the absence of dialogue between the executive and the judiciary on the problems arising from the Italian jurisprudence denying state immunity for international crimes.

As to the ambiguous judicial strategies pursued by the Italian government in the outstanding proceedings against Germany, very little has changed vis-à-vis the pre-Sentenza situation. ${ }^{20}$ The government supports Germany's position with respect to most of the key aspects of the dispute (such as the absence of jurisdiction of Italian courts, the unconditional obligation to comply with the 2012 ICJ Judgment, the prescription of the actions), save that it strongly contests its duty to hold Germany harmless from any WWII reparation claims by Italian nationals, a duty allegedly flowing from the 1947 Peace Treaty and the bilateral 1961 Bonn Agreements. ${ }^{21}$

On the other side, the most salient feature of Germany's recent conduct is a refusal to participate in the compensation proceedings resumed in Italian courts in the wake of Sentenza 238/2014. In all such proceedings Germany has been and will

\footnotetext{
${ }^{18}$ For the text of the declaration, see Italy, 'Declarations recognizing the jurisdiction of the Court as compulsory', (25 November 2014), available at https://www.icj-cij.org/en/declarations/it; for a comment, see Paolo Palchetti, "“A key institution for interpreting international law and guaranteeing global compliance with its provisions": la dichiarazione italiana di accettazione della competenza della Corte internazionale di giustizia', Rivista di diritto internazionale 98 (2015), 114-125.

${ }^{19}$ See Corte di Cassazione, Judgment of 29 October 2015, No 43696/2015 (In the Matter of Criminal Proceedings against Dobrivoje Opačić; Podrute Massacre case), finding Serbia liable to pay damages to the heirs of victims of the downing of a military helicopter operating on a humanitarian mission during the 1990s Yugoslav wars.

${ }^{20}$ See, eg, Tribunale di Firenze, Judgment of 6 July 2015, No 2469/2015 (Simoncioni v Germany), 3-4.

${ }^{21}$ Such a duty would most clearly emerge from the 'hold-harmless clause' of Art 2(2) of the Agreement between the Federal Republic of Germany and Italy on the Settlement of Certain Property-Related, Economic and Financial Questions (Bonn, 2 June 1961), German and Italian version published in Bundesgesetzblatt II 26 June 1963 No 19, 668. See also Stefan Kadelbach, chapter 'State Immunity, Individual Compensation for Victims of Human Rights Crimes, and Future Prospects', and Andreas von Arnauld, chapter 'Deadlocked in Dualism', in this volume.
} 
be a respondent in absentia, ${ }^{22}$ as well as the addressee of a number of default judgments awarding damages and costs. Germany has consistently communicated to the courts that its decision stemmed from the consideration that such proceedings constituted a violation of the principles of international law upheld by the 2012 ICJ Judgment and has made reference to a diplomatic Note Verbale of 5 January 2015 from Germany's embassy in Rome to the Italian Ministry of Foreign Affairs for further explanation. ${ }^{23}$ According to this Note Verbale, Sentenza 238/2014 'cannot change anything of what has been found by the ICJ with respect to the content and scope of the jurisdictional immunity enjoyed by Germany before Italian courts' ${ }^{24}$ Indeed, the Note continues, pursuant to a well-settled rule of international law 'the principle of State immunity cannot be limited by the domestic law of a State, not even by fundamental principles of the national constitutional order ${ }^{25}$ The Note also takes the view that the plaintiffs would be able to enjoy equivalent protection before German courts. ${ }^{26}$ It concludes with a 'precautionary warning ${ }^{27}$ reminding the Italian government of the risk of further litigation and outlining the consequences arising from the continuation of judicial proceedings in terms of state responsibility and reparation.

Germany has thus chosen a confrontational posture vis-à-vis Italian courts, which have at times reacted with irritation and bewilderment. ${ }^{28}$ Crucially, Germany has also taken an uncompromising attitude by refusing to accede to the requests from several courts to negotiate an out-of-court settlement with the plaintiffs (where the latter were heirs of the victims) and Italy through conciliation or mediation by a

\footnotetext{
${ }^{22}$ See, eg, Tribunale di Piacenza, Judgment of 28 September 2015, No 723/2015 (Rabizzoni v Germany); Corte d'Appello di Brescia, Judgment of 6 June 2016, No 515/2016 (Currà v Germany); Corte di Cassazione, Judgment of 13 January 2017, No 762/2017 (Parrini v Germany).

${ }^{23}$ Note Verbale of 5 January 2015, 2/15, RK 553.32.

${ }^{24}$ Ibid, para 3 (translated by the author).

${ }^{25}$ Ibid, para 4 (translated by the author, emphasis added).

${ }^{26}$ Ibid, para 6. This argument is particularly difficult to follow, as Germany is perfectly aware that all IMIs' claims have in the past been rejected by German courts, including the Federal Constitutional Court (Order of 28 June 2004, 2 BvR 1379/01, BVerfGK 3, 277). Although such courts have resorted to a variety of arguments for that purpose, the veritable stumbling block for IMIs' claimsand probably the most controversial aspect lying at the origin of the whole dispute between Germany and Italy - was their ineligibility for compensation under the funds made available by the German Foundation 'Remembrance, Responsibility and Future' (Erinnerung, Verantwortung und Zukunft) due to their freshly rediscovered, allegedly inalienable entitlement to prisoner of war (POW) status at the time of their deportation (see Section 11(3) of the German Law of 2 August 2000 establishing the Foundation, Bundesgesetzblatt I 11 August 2000 No 38, 1263). For further detail, see ECtHR, Associazione Nazionale Reduci v Germany, Decision of 4 September 2007, Application No 45563/04, 3-8.

${ }^{27}$ Note Verbale 2/15 (n 23), para 8 (translated by the author).

${ }^{28}$ Including the Court of Cassation, which has stigmatized the unorthodox means employed by Germany for communicating with the Court and accordingly declared inadmissible a letter from Germany's embassy enclosing the Note Verbale discussed in the text; see Corte di Cassazione, Judgment of 29 July 2016, No 15812/2016 (Gamba v Germany), para 1; see also Tribunale di Firenze, Judgment No 2469/2015 (n 20), 17.
} 
commission chosen by the parties and including lawyers with an expertise in public international law. The Tribunal of Florence has been the most creative in this context by submitting its own proposed settlements to the parties. For instance, the proposal in the Alessi case envisaged a study or cultural visit to Germany worth $€ 15,000$ for each of the three plaintiffs, in exchange for the withdrawal of their compensation claims. $^{29}$ In the face of Germany's tacit dismissal of these proposals, the courts proceeded to adjudicate the merits of the cases in favour of the plaintiffs and awarded them substantial damages. ${ }^{30}$ On its part, the Italian government has also never expressed any interest in participating in these non-adversarial conciliatory procedures. Given the apparent disengagement of the two governments, the Italian courts were trying to make the best out of the ICJ's consideration that the unredressed grievances of Italian victims of Nazi crimes 'could be the subject of further negotiation $(. .$.$) with a view to resolving the issue'. 31$

Despite the obiter dictum nature of this remark by the ICJ, and if only for reasons of transparency, the Italian and German governments should clearly communicate to the international community whether and to what extent they have carried out such negotiations in good faith. Most significantly, do they think they have already reckoned with the historical 'justice/equity gap', ${ }^{32}$ which has uniquely affected IMIs and similarly situated victims? Are monuments and historical reports sufficient to close in a dignified way this specific and tragic chapter of WWII ? ${ }^{33}$ Since theyas well as scholars ${ }^{34}$ _disagree on the nature and scope of the labyrinthine postWWII regulation of reparations by Germany, why has arbitration or similar means of dispute settlement not been contemplated?

While answers to these questions are long overdue, the present situation may be regarded as a recipe for failure, which especially runs against the interest of the individual direct victims who, being now in their (late) nineties, are sadly passing away at an accelerating rate. Whereas further litigation will likely perpetuate the 'zero-sum game' 35 that the whole dispute so far has turned out to be, another key

\footnotetext{
${ }^{29}$ Tribunale di Firenze, Order of 23 March 2015 (Alessi v Germany). See the case commentary by Serena Forlati, Italian Yearbook of International Law 25 (2015), 497-509, at 502.

${ }^{30}$ See, eg, Tribunale di Firenze, Judgment of 22 February 2016, No 691/2016 (Donati v Scheungraber, Stommel and Germany).

${ }^{31} \mathrm{ICJ}$, Jurisdictional Immunities (n 2), para 104.

${ }^{32}$ Michael Bothe, 'Remedies of Victims of War Crimes and Crimes against Humanities: Some Critical Remarks on the ICJ's Judgment on the Jurisdictional Immunity of States', in Anne Peters/ Evelyne Lagrange/Stefan Oeter/Christian Tomuschat (eds), Immunities in the Age of Global Constitutionalism (Leiden: Brill Nijhoff 2015), 99-115, at 110-111; 113-114.

${ }^{33} \mathrm{Cf}$ Motion No 1-01375 of the Chamber of Deputies of the Italian Parliament (n 7).

${ }^{34}$ Compare Christian Tomuschat, 'The Case of Germany v. Italy before the ICJ', in Peters, Immunities 2015 (n 32), 87-98, at 95-98, with Michael Bothe, 'The Decision of the Italian Constitutional Court Concerning the Jurisdictional Immunities of Germany', Italian Yearbook of International Law 24 (2014), 25-35, at 31-35.

${ }^{35}$ Francesco Francioni, 'Access to Justice and Its Pitfalls: Reparation for War Crimes and the Italian Constitutional Court', Journal of International Criminal Justice 14 (2016), 629-636, at 633.
} 
question remains: why have the two governments - at least throughout the past 20 years - not meaningfully embraced 'legal peace' as the overarching public good guiding their actions? Broadly understood, legal peace would involve a negotiated settlement agreement prescribing the termination of the outstanding judicial proceedings against Germany in exchange for a reasonable compensatory scheme available to the plaintiffs and co-funded by the two governments.

In the first place, legal peace would be in the interest of the victims, but it would also be in the interest of the integrity of the international and national legal orders. Taking a confrontational, unbending position is unhelpful to both sides when national supreme courts plausibly invoke fundamental constitutional principles as the last bulwark against international law rules. Such a position only exacerbates the impression that international law and domestic legal orders are two irreconcilable worlds apart. Dialogue and interaction among the relevant actors, as well as salutary competition between and mutual reinforcement of international and domestic law, seem necessary instead. Moreover, the achievement of legal peace has always been a crucial consideration for German and other governments when dealing with the outstanding problems arising from WWII reparation regimes.

\section{Why the French Railroad Deportees and Not IMIs?}

It is frequently suggested that the time factor runs against the soundness of the reparation claims of IMIs and similarly situated Italian victims of Nazi crimes. For instance, it has been stated that, as compared to state immunity litigation involving torture and comparable crimes 'of current or recent regimes', ${ }^{36}$ the issue of IMIs makes a bad case because it 'concerns crimes committed more than one generation ago'. ${ }^{37}$ This would imply that '[e]ven if we do not accept any formal prescription for the prosecution of such egregious crimes, the lapse of time does weaken the claims. 38

On the basis of intertemporal fairness and other grounds, I think that the lapse of time does weaken the argument that immunity should be lost when the defendant state is accused of grave breaches of human rights, thereby creating the possibility that the relevant 'ancient' conduct might come to be reassessed through the prism of modern legal achievements and standards. I have always had the impression that a significant part of the criticism levelled against the Italian Ferrini jurisprudence ${ }^{39}$

\footnotetext{
${ }^{36}$ Anne Peters, 'Let Not Triepel Triumph-How To Make the Best Out of Sentenza No. 238 of the Italian Constitutional Court for a Global Legal Order', EJIL:Talk!, (22 December 2014), available at www.ejiltalk.org/let-not-triepel-triumph-how-to-make-the-best-out-of-sentenza-no-238-of-theitalian-constitutional-court-for-a-global-legal-order-part-i.

${ }^{37}$ Ibid.

${ }^{38}$ Ibid.

${ }^{39}$ Corte di Cassazione, Judgment of 11 March 2004, No 5044/2004 (Ferrini). As is well-known, this is the landmark decision where for the first time a foreign state was denied immunity from the jurisdiction of Italian courts in a case involving international crimes.
} 
stems from these intertemporal considerations, ${ }^{40}$ where 'intertemporal' is not necessarily used in a technical sense but also refers to the contemporary uneasiness of Italy and Germany, and Italians and Germans alike, about discussions that might reopen the old wounds of their respective national history. With its historical overtones, the German-Italian controversy has unduly monopolized the 'human rights versus immunity' debate, thus detracting attention from the legal advancement that might result from the contemporary affirmation of a narrow human rights limitation to state immunity, namely, one confined to the most serious breaches of human rights that have not been, and cannot be, redressed by the responsible state.

Conversely, I do not think that the passage of time per se constitutes a valid reason for dismissing the substantive claim for reparation of a whole class of victims of war crimes, even though such crimes date back to many decades ago. This is especially true in our case where the responsibility for those crimes is acknowledged and what is disputed is only whether Germany has fully discharged its obligation to provide reparation for the resulting injuries. Rather, the time factor should encourage a sense of urgency in the governments' approaches to, at the very least, the outstanding claims of Italian WWII direct victims, that is, the survivors who are now in their (late) nineties.

It is precisely this sense of urgency - and the determination to attain a lasting legal peace in the face of increasing WWII litigation before national courts - that, as recently as 2014, led to an agreement between the US and France on compensation for the so-called French railroad deportees who were excluded from prior French reparation programmes. ${ }^{41}$ The basic bargain is well-known, as it builds upon extensive US practice in this area: ${ }^{42}$ France made US\$60 million available to satisfy claims of uncompensated railroad deportees, ${ }^{43}$ while the US was obligated 'to

\footnotetext{
${ }^{40}$ See, eg, Carlo Focarelli, Diritto internazionale (Padua: Cedam $4^{\text {th }}$ ed 2017), at 332: 'Quel che conta è circoscrivere l'eccezione umanitaria a specifici crimini commessi oggi o che verranno commessi in futuro-abbandonando l'idea di "punire" $i$ crimini passati, tanto meno di un unico Stato, tenuto conto che pressoché tutti gli Stati ne hanno commessi e non è chiaro quanto indietro nel tempo si debba andare' ('What is important is to circumscribe the human rights exception to specific crimes which are committed today or will be committed in the future, thereby abandoning the idea of 'punishing' past crimes, especially crimes of a single state, taking into account that nearly all states have committed such crimes and it is not clear how far back in time we should go' (translated by the author)).

${ }^{41}$ Agreement on Compensation for Certain Victims of Holocaust-Related Deportation from France Who Are not Covered by French Programs, 8 December 2014, in force 1 December 2015, TIAS No 15-1101. See Ronald Bettauer, 'A Measure of Justice for Uncompensated French Railroad Deportees during the Holocaust', ASIL Insights, (1 March 2016), available at https://www.asil.org/ insights/volume/20/issue/5/measure-justice-uncompensated-french-railroad-deportees-during-holo caust. See also Filippo Fontanelli, chapter 'Sketches for a Reparation Scheme', in this volume.

${ }^{42}$ For an exhaustive account by the key US negotiator, see Stuart Eizenstat, Imperfect Justice: Looted Assets, Slave Labor, and the Unfinished Business of World War II (New York: Public Affairs 2004).

${ }^{43}$ Agreement on Compensation for Certain Victims of Holocaust-Related Deportation from France, 2014 (n 41), Art 4(1).
} 
recognize and affirmatively protect the sovereign immunity of France within the United States legal system with regard to Holocaust deportation claims and, consistent with its constitutional structure, to undertake all actions necessary to ensure an enduring legal peace at the federal, state, and local levels of the Government of the United States of America'. ${ }^{4}$

The reason for mentioning the 2014 French Railroad Deportees Agreement is by no means to suggest that it should be taken as a template for a similar outcome to potential negotiations on the unresolved issue of Italian victims of Nazi crimes. The historical and legal backgrounds are obviously different. Instead, the Agreement is an indication that states are still reckoning with their historical wrongs and that, under the pressure of litigation and legislative initiatives jeopardizing their entitlement to immunity, ${ }^{45}$ they are willing to settle past accounts.

Indeed, the French Railroad Deportees Agreement is an example of the key role played by state immunity litigation before domestic courts in the area of human rights and international crimes. Whichever way one leans in the 'immunity versus human rights' debate, it cannot reasonably be denied that often times and for the sake of legal peace such litigation prompts the relevant states to go back to the negotiating table, take a fresh look at the underlying issues, and accordingly devise fair arrangements affording a decent measure of justice to uncompensated victims. At the time of writing, it is uncertain whether that scenario will be replicated, even to a degree, with regard to the claims lodged by IMIs and comparable victims before Italian courts. Nevertheless, we should not overlook that, were it not for the Italian Ferrini jurisprudence, the tragic and paradoxical historical trajectory of IMIs would largely have been forgotten, as has been true for too many decades.

In this context, it is clear that US immunity practice is paradigmatic. That practice is multifarious and constantly evolving and it would be unwarranted to briskly marginalize it altogether as completely detached from the international legal framework. ${ }^{46}$ Insofar as it is relevant for current purposes, such practice includes a substantial number of WWII reparations cases that have spurred intergovernmental settlements and were dismissed when those settlements were finalized. The most famous examples involve Austria, ${ }^{47}$

\footnotetext{
${ }^{44}$ Ibid, Art 2(2). See also ibid, Art 5.

${ }^{45}$ For details regarding cases and bills challenging France's jurisdictional immunity in the US, see Bettauer, 'A Measure of Justice' 2016 (n 41).

${ }^{46}$ Contra Thomas Giegerich, 'The Holy See, a Former Somalian Prime Minister, and a Confiscated Pissarro Painting: Recent US Case Law on Foreign Sovereign Immunity', in Peters, Immunities 2015 (n 32), 51-69, at 69. See further, section IV of this chapter.

${ }^{47}$ Agreement Between the Austrian Federal Government and the Government of the United States of America Concerning the Austrian Fund 'Reconciliation, Peace and Cooperation', 24 October 2000, in force 1 December 2000, 40 ILM 523 (2001); Joint Statement and Exchange of Notes Between the United States and Austria Concerning the Establishment of the General Settlement
} 
France, ${ }^{48}$ and Germany. ${ }^{49}$ In all these instances, the mounting pressure from WWII-related litigation against certain companies and agencies of those states, and/or against those states as such, was a fundamental factor paving the way for the negotiations leading up to the settlement agreements. ${ }^{50}$

Although the details of the various arrangements may be significantly different, their common rationale, or grand bargain, is a constant feature: an exclusive compensatory mechanism funded by the responsible state (and often co-funded by the companies implicated in the relevant crimes) is set up in exchange for legal peace in the forum state; legal peace involves the termination or suspension of judicial proceedings against the responsible state and its companies, as well as a bestefforts obligation on the forum state's executive to prevent and oppose any future challenges to the responsible state's immunity, or at least challenges arising from claims covered by the pertinent agreement.

As to the practice concerning Germany, it is usually recalled that US Holocaust litigation was crucial for the conclusion of the 2000 Agreement establishing the Foundation 'Remembrance, Responsibility and Future' (Erinnerung, Verantwortung und Zukunft). ${ }^{51}$ By contrast, less attention is paid to an earlier WWII reparations agreement ${ }^{52}$ stipulated in 1995 by a recently reunified Germany in the wake of the Princz affair, which had hitherto resulted in a decade-long diplomatic action by the US and one of the most famous cases discussing (and rejecting) a ius cogens exception to state immunity. ${ }^{53}$ The 1995 Agreement was thus

Fund for Nazi-Era and World War II Claims, 17 January 2001, in force 23 January 2001, 40 ILM 565 (2001).

${ }^{48}$ In addition to the 2014 Agreement between France and the US discussed earlier (n 41), see Agreement between the Government of the United States of America and the Government of France Concerning Payments for Certain Losses Suffered During World War II, 18 January 2001, in force 5 February 2001, 2156 UNTS 281, as amended 30-31 May 2002, and 21 February 2006.

${ }^{49}$ See text accompanying notes 51 and 52 .

${ }^{50}$ See Eizenstat, Imperfect Justice 2004 (n 42), 258; 321; 342: '[I]t cannot be doubted that, without the suits, the pressures they generated, and the involvement of the U.S. government they occasioned, the massive settlements would never have occurred'. Another accompanying key factor for the successful outcome of the negotiations in question was the threat of financial sanctions against the companies of the states concerned that were implicated in WWII crimes (eg insurance or manufacturing companies). This threat was repeatedly made by various US federal and local authorities.

${ }^{51}$ Agreement Concerning the Foundation 'Remembrance, Responsibility and the Future', 17 July 2000, in force 19 October 2000, 39 ILM 1298 (2000). See, eg, Bothe, 'The Decision of the Italian Constitutional Court' 2015 (n 34), 34; Roland Bank, 'The New Programs for Payments to Victims of National Socialist Injustice', German Yearbook of International Law 44 (2001), 307-352, at 309; 313-314; 321-322; 325-327; Leora Bilsky, 'Transnational Holocaust Litigation', European Journal of International Law 23 (2012), 349-375, at 353-355.

${ }^{52}$ Agreement Concerning Final Benefits to Certain United States Nationals Who Were Victims of National Socialist Measures of Persecution, 19 September 1995, and Supplementary Agreement Effected by Exchange of Notes, 25 January 1999. The 1995 Agreement is reproduced in 35 ILM 193 (1996), with an introductory note by Ronald Bettauer.

${ }^{53}$ Princz v Germany, 26 F 3d 1166 (DC Cir, 1 July 1994). See also Sampson v Germany, 250 F 3d 1145 (7th Cir, 23 May 2001). 
a sort of ad personam arrangement (and an effective exercise of diplomatic protection) making DM (Deutsche Mark) 3 million available '[f]or the prompt settlement of known cases of compensation claims ${ }^{, 54}$ advanced by victims of Nazi persecution who were US nationals at the time of the injury. ${ }^{55}$ The close link between state immunity litigation and ensuing intergovernmental negotiation and settlement is crystal clear.

Most important, legal peace was actually achieved as a result of such diplomatic activity. US courts, including the US Supreme Court, ${ }^{56}$ cooperated in good faith to that end by rejecting all remaining Holocaust claims covered by those agreements and lodged against the states concerned and/or their agencies and companies. The courts justified their decisions on a variety of grounds, which prominently feature the non-justiciability of political questions and international comity. ${ }^{57}$

Unsurprisingly, the current residues of US Holocaust litigation precisely concern situations involving either an absence of reparations agreements between the US and the respondent states along the lines mentioned earlier or subject matters that were not (or not clearly) dealt with by such agreements. The first category of situations includes a number of high-profile disputes against Hungary and several of its state agencies for their role in the mass deportation of Hungarian Jews towards the end of WWII (which resulted in the extermination of more than 500,000 persons) and the ensuing systematic deprivation of their property and assets. ${ }^{58}$ The second category involves, most significantly, cases relating to cultural property confiscated by the Nazis and their accomplices during the Third Reich. Thus, Germany was recently denied immunity in a prominent dispute involving a complaint for the restitution of precious medieval devotional objects known as the Welfenschatz and currently housed by the Museum of Decorative Arts in Berlin. ${ }^{59}$ The plaintiffs, who are

\footnotetext{
${ }^{54}$ Agreement Concerning Final Benefits, 1995 (n 52), Art 2(1) (emphasis added). Hugo Princz and thirteen similarly situated victims were compensated with these funds.

${ }^{55}$ Ibid, Art 1.

${ }^{56}$ American Insurance Association v Garamendi, 539 US 396 (Sup Ct, 23 June 2003). The Supreme Court struck down - although with a bare majority of 5:4-a California statute imposing on insurers doing business in California a duty to disclose information relating to Nazi-era insurance policies. The statute was found to be unduly interfering with the US President's foreign affairs power as expressed in this context by the 2000 German Foundation Agreement.

${ }^{57}$ On the German Foundation Agreement, see Ungaro-Benages v Dresdner Bank AG, 379 F.3d 1227 (11th Cir, 3 August 2004). For the agreements involving Austria and France, see Whiteman $v$ Dorotheum Gmbh \& Co. Kg, 431 F.3d 57 (2nd Cir, 23 November 2005), and Freund v France, 592 F.Supp 2d 540 (SDNY, 19 December 2008); Scalin v Société Nationale des Chemins de Fer Français, No 15-cv-03362, 26 March 2018 (District Court for the Northern District of Illinois [ND IIl] 2018).

${ }^{58}$ See, eg, Simon v Hungary, No 17-7146, 28 December 2018 (DC Cir 2018); de Csepel v Hungary, 859 F.3d 1094 (DC Cir, 20 June 2017).

${ }^{59}$ Philipp v Germany, 248 F. Supp. 3d 59 (DDC 2017). The Court of Appeals largely affirmed the first instance decision, see Philipp v Germany, 894 F.3d 406 (DC Cir 2018). On 2 July 2020, a petition for a writ of certiorari lodged by Germany was granted by the US Supreme Court.
} 
legal successors to the original owners, successfully claimed (so far) that these art objects were forcibly sold to the state of Prussia (a then political subdivision of the Third Reich) in 1935, as a result of persecution against the Jewish 'sellers'. Crucially, the courts held that the absence of any intergovernmental agreements with Germany covering the restitution of Nazi-looted $\operatorname{art}^{60}$ was a chief reason for dismissing all German defences based on an encroachment of the foreign affairs power of the US President, non-justiciability, international comity, and forum non conveniens. ${ }^{61}$ The 1998 Washington Conference Principles on Nazi-Confiscated Art, ${ }^{62}$ as implemented by Germany through the creation of an Advisory Commission for the Return of Cultural Property Seized as a Result of Nazi Persecution, were no bar to that conclusion, given the non-binding nature of the former instrument and the ineffectiveness of the latter remedy.

The reason for discussing this US practice is that it provides a most useful lesson to the German and Italian governments: dialogue and non-adversarial means of dispute settlement, transparently implemented with the involvement of the victims, are the only avenues to achieve legal peace and resolve the current impasse. Such conduct would also dispose of any unpleasant feelings that the US, due to its political and economic leverage, is capable of accomplishing in this area what is beyond the reach of other states.

Reliance on US Holocaust litigation and practice would have provided significant support to the Italian Ferrini jurisprudence. The Ferrini Court instead preferred to quote the controversial US terrorism exception to state immunity and related US judicial decisions. ${ }^{63}$

\section{North American Remedies Against Immunities}

The ICJ's holding that immunity gives rise to a right enjoyed by states under customary international law should not be taken as an obvious and granitic conclusion. ${ }^{64}$ A more comprehensive and nuanced position was possible and would have been preferable. ${ }^{65}$ Anne Peters, for instance, points out that immunities are a 'messy

\footnotetext{
${ }^{60}$ The German Foundation Agreement, 2000 (n 51), basically ignores this subject matter.

${ }^{61}$ DDC, Philipp (n 59), 74-87; DC Cir, Philipp (n 59), 416-418.

${ }^{62}$ This set of principles was endorsed on 3 December 1998 by 44 states and 13 NGOs participating in the Washington Conference on Holocaust Era Assets. For a follow-up, see Terezín Declaration on Holocaust Era Assets and Related Issues, adopted on 30 June 2009 by 46 states. For background, see Eizenstat, Imperfect Justice 2004 (n 42), 187-204.

${ }^{63}$ Corte di Cassazione, Judgment No 5044/2004 (n 39), para 10.2.

${ }^{64} \mathrm{ICJ}$, Jurisdictional Immunities (n 2), paras 53 and 56.

${ }^{65}$ Riccardo Pavoni, 'An American Anomaly? On the ICJ's Selective Reading of United States Practice in Jurisdictional Immunities of the State', Italian Yearbook of International Law 21 (2011), 143-159.
} 
affair' ${ }^{66}$ as they 'oscillate between law, politics, and comity', ${ }^{67}$ they are 'bastards', ${ }^{68}$ she insists, created by the 'engagement of law with politics, of international law with domestic law, of public law with private law' ${ }^{69}$ Further, she convincingly highlights that, 'to the extent that immunities do pertain to the legal realm', ${ }^{70}$ the relentless interaction of pertinent international and national jurisprudence makes this area of law 'dynamic, complex, and partly inconsistent'.

Anne Peters is in good company. In addition to a sizable scholarship, ${ }^{72}$ her views are echoed in the Kazemi decision ${ }^{73}$ of the Supreme Court of Canada involving (and upholding) state immunity for torture, a decision delivered a few days before Sentenza 238/2014. The Supreme Court noted: '[S]tate immunity is not solely a rule of customary international law. It also reflects domestic choices made for policy reasons, particularly in matters of international relations' ${ }^{74}$ The Court also made clear that comity provides a rationale for the recognition of immunity additional to, inter alia, sovereign equality, ${ }^{75}$ thus essentially endorsing the same approach that famously informs US jurisprudence. ${ }^{76}$

\footnotetext{
${ }^{66}$ Anne Peters, 'Immune against Constitutionalisation?', in Peters, Immunities 2015 (n 32), 1-19, at 1 .

${ }^{67}$ Ibid.

${ }^{68}$ Ibid, 17.

${ }^{69}$ Ibid. See also ibid, 5 ('international or rather trans-national law of immunities').

${ }^{70}$ Ibid, 5 .

${ }^{71}$ Ibid, 2 .

${ }^{72}$ See, eg, Jasper Finke, 'Sovereign Immunity: Rule, Comity or Something Else?', European Journal of International Law 21 (2010), 853-881; Riccardo Luzzatto, 'La giurisdizione sugli Stati stranieri tra Convenzione di New York, norme internazionali generali e diritto interno', Comunicazioni e studi 23 (2007), 1-21; Lee M Caplan, 'State Immunity, Human Rights, and Jus Cogens: A Critique of the Normative Hierarchy Theory', American Journal of International Law 97 (2003), 741-781.
}

${ }^{73}$ Supreme Court of Canada, Kazemi Estate v Islamic Republic of Iran, 2014 SCC 62 (10 October 2014).

${ }^{74}$ Ibid, para 45. See also ibid, para 169: 'State immunity is a complex doctrine that is shaped by constantly evolving international relations. Determining the exceptions to immunity requires a thorough knowledge of diplomacy and international politics and a careful weighing of national interests'.

${ }^{75}$ Ibid, paras 2, 36-38, 62.

${ }^{76}$ Verlinden BVv Central Bank of Nigeria, 461 US 480, 486 (Sup Ct, 23 May 1983); Dole Food Co $v$ Patrickson, 538 US 468, 479 (Sup Ct, 22 April 2003); Republic of Austria v Altmann, 541 US 677, 43 ILM 1425 (2004), 1428, 1430, 1431 (Sup Ct, 7 June 2004). The unanimous opinion of the US Supreme Court in Venezuela $v$ Helmerich signals a more internationally friendly approach to the rationale and operation of the doctrine of state immunity which was arguably dictated by the increasing tensions generated by the US practice that will now be discussed in the main text; see Bolivarian Republic of Venezuela $v$ Helmerich \& Payne International Drilling Co., 137 S.Ct. 1312 (Sup Ct, 1 May 2017). The Supreme Court held that a non-frivolous argument by the plaintiffs is an insufficient standard to sustain a claim that property has been taken by a foreign state in violation of international law, as required by the expropriation exception under Section 1605(a)(3) of the Foreign Sovereign Immunities Act (FSIA), 28 USC, Sections 1330, 1332, 1391(f), 1441(d), and 
These unprecedented observations by the Supreme Court of Canada were prompted by Canada's adoption, just a few weeks after the 2012 ICJ Judgment, of a terrorism exception to state immunity, according to which a foreign state does not enjoy immunity in proceedings relating to loss or damage arising from that state's terrorist activity (carried out on or after 1 January 1985), and provided the same state has been included in a list of supporters of terrorism by the government. ${ }^{77}$ This background led the Supreme Court to conclude that 'the amendment to the SIA [State Immunity Act] brought by Parliament in 2012 demonstrates that forum states (...) have a large and continuing role to play in determining the scope and extent of state immunity'. 78

The persistent dynamism of the law of international immunities seems beyond question. Despite the widespread impression that international court decisions like the Jurisdictional Immunities Judgment ${ }^{79}$ and the Jones Judgment ${ }^{80}$ are bound to yield a desirable stabilization of the pertinent practice, this field of law seems more vibrant than ever and continues to generate high-profile disputes. Two relevant cases are pending before the ICJ. One case ${ }^{81}$ involves the immunity from criminal jurisdiction of a senior state official and the inviolability of diplomatic premises, whereas the other ${ }^{82}$ - which is much more interesting in our context-concerns the alleged responsibility of the US for having repeatedly denied Iran's immunity from adjudication and execution in the framework of the notorious legislation ${ }^{83}$ targeting state sponsors of terrorism designated as such by the US executive (currently, Iran,

1602-1611. The Court found support for its holding in the history and basic objectives of the FSIA. It stated that the FSIA 'for the most part embodies basic principles of international law long followed both in the United States and elsewhere' (ibid, 1319 (emphasis added)), and that to grant foreign states immunity from suit in US courts "recognizes the "absolute independence of every sovereign authority" and helps to "induc[e]" each nation state, as a matter of "international comity", to "respect the independence and dignity of every other", including our own' (ibid, quoting Berizzi Brothers Co. v S.S. Pesaro, 271 US 562 (Sup. Ct., 7 June 1926)).

The unparalleled US expropriation exception to state immunity constitutes the legal basis of an overwhelming part of the Holocaust jurisprudence discussed in section III of this chapter. The exception clearly implicates iure imperii acts of foreign states, although US courts often seek to circumvent this point.

${ }^{77}$ Justice for Victims of Terrorism Act (JVTA), Bill C-10, in force 13 March 2012, Section 4(1) and SIA, as amended by the JVTA, Section 6(1) and (2).

${ }^{78} \mathrm{SCC}$, Kazemi Estate (n 73), para 44.

${ }^{79} \mathrm{ICJ}$, Jurisdictional Immunities (n 2).

${ }^{80} \mathrm{ECtHR}$, Jones and Others $v$ The United Kingdom, Judgment of 14 January 2014, Applications Nos 34356/06 and 40528/06.

${ }^{81}$ ICJ, Immunities and Criminal Proceedings (Equatorial Guinea v France), Order of 7 December 2016 (Provisional Measures), ICJ Reports 2016, 1148, Judgment of 6 June 2018 (Preliminary Objections).

${ }^{82}$ ICJ, Certain Iranian Assets (Iran v United States of America), Judgment of 13 February 2019 (Preliminary Objections). It must be noted that, with the latter judgment, the ICJ has upheld the preliminary objection to its jurisdiction raised by the US with respect to Iran's claims involving jurisdictional immunities, while dismissing the other objections, ibid, para 80.

${ }^{83}$ Currently codified at FSIA (n 76), Section 1605A. 
North Korea, Sudan, and Syria). In addition, the potentially powerful stabilizing factor represented by the UNCSI is languishing in the ratification process: more than 15 years after its adoption, only 22 states have consented to be bound by this convention, whereas 30 ratifications are necessary for its entry into force; most worryingly, however, only one state has ratified it over the last five years, and many 'key' ${ }^{84}$ states, such as Germany and the UK, appear uninterested in becoming parties. One plausible explanation is that the large majority of states are unwilling to sacrifice their scope for manoeuvre in immunity issues to the altar of legal predictability and harmonization resulting from multilateral treaty obligations.

Yet the US and Canadian terrorism exceptions to state immunity, together with the Italian Ferrini and Sentenza 238/2014 jurisprudence, remain the most controversial manifestations of the contemporary practice in the area of international immunities. Nearly 25 years after its enactment, damages awarded under the US exception have now reached much-feared 'astronomic dimensions' ${ }^{85}$ Iran is debtor to a multitude of (largely unpaid) judgments awarding damages for over US\$56 billion. ${ }^{86}$ Most significantly, a number of legislative instruments and judicial decisions have targeted various types of property held by Iran or its instrumentalities in the US, thereby paving the way for execution against them. In many instances, such property is apparently used or intended for governmental purposes, including the financial assets of the Central Bank of Iran (Bank Markazi) and state cultural objects. ${ }^{87}$ These categories of sovereign property should thus be immune under international law.

The situation became particularly troublesome for the Iranian authorities when in August 2012 the US Congress approved, and the President signed into law, the Iran Threat Reduction and Syria Human Rights Act, ${ }^{88}$ which contains a section removing any obstacle to execution against certain Iranian financial assets specifically identified as those that had already been the subject of restraining orders in a case under the terrorism exception. ${ }^{89}$ These assets amount to some US\$1.75 billion in cash proceeds of securities owned by Bank Markazi. Soon after the US Supreme Court upheld this ad hoc legislation in the 2016 Bank Markazi decision, ${ }^{90}$ Iran filed its

\footnotetext{
${ }^{84}$ If only for the volume of state immunity practice which involves them.

${ }^{85}$ Tomuschat, 'The Case of Germany v. Italy' 2015 (n 34), 94.

${ }^{86}$ ICJ, Certain Iranian Assets (n 82), Application Instituting Proceedings, 14 June 2016, Appendix 2, Table 2.

${ }^{87}$ ICJ, Certain Iranian Assets (n 82), Application Instituting Proceedings, 14 June 2016, Appendix 2, Table 3. With regard to cultural property, note, however, the decision of the US Supreme Court in the Rubin case, which effectively halted attempts of attaching priceless Persian artefacts owned by Iran and located in the US, Rubin v Islamic Republic of Iran, 138 S.Ct. 816 (2018) (Sup Ct, 21 February 2018).

${ }^{88}$ Iran Threat Reduction and Syria Human Rights Act, 10 August 2012, 22 USC Section 8772.

${ }^{89}$ Peterson et al $v$ Islamic Republic of Iran et al, Case No 10 Civ 4518 (BSJ) (GWG) (District Court for the Southern District of New York).

${ }^{90}$ Bank Markazi v Peterson, 136 S.Ct. 1310 (Sup Ct, 20 April 2016). See Kristina Daugirdas/Julian D Mortenson, 'Contemporary Practice of the United States Relating to International Law', American Journal of International Law 110 (2016), 554-595, at 555-562.
} 
application with the ICJ. The Supreme Court merely considered, and ruled out, a possible violation of separation-of-powers principles by the 2012 Act. It did not even mention international law. Only Chief Justice Roberts, in his powerful dissenting opinion, underscored that the disputed legislation 'strips the Bank of any protection that federal common law, international law, or New York State law might have offered against respondents' claims'. 91

US plaintiffs holding judgments against Iran have now found a precious ally across the northern border. One of the most salient aspects of the Canadian terrorism exception is a provision according to which Canadian courts 'must recognize a judgment of a foreign court' 92 in favour of a person who has suffered losses or damages as a result of terrorist activities by a state supporter of terrorism listed as such in Canada (presently, Iran and Syria). This provision has already been set in motion. For instance, a major case involves twelve US judgments against Iran that have been granted exequatur and whose enforcement proceedings in Canada are well underway. ${ }^{93}$ Attachment has successfully been sought against two bank accounts held in the name of Iran's embassy and real estate allegedly hosting Iranian cultural centres located in Ottawa and Toronto. ${ }^{94}$ To be sure, Canada's immunity statute makes iure imperii property held by state supporters of terrorism generally subject to execution, with the exception of diplomatic property, property that has cultural or historical value, and-possibly-military property. ${ }^{95}$ In the Tracy case, both the buildings hosting Iranian cultural centres and the embassy's bank accounts were found not to have 'cultural or historical value'; ${ }^{96}$ nor were they diplomatic property, ${ }^{97}$ given that they were listed on Canada's Department of Foreign Affairs website as 'Iran's Non-Diplomatic Assets in Canada'. The conclusion that the Iranian property at stake was not entitled to immunity from execution 'under either domestic or international

\footnotetext{
${ }^{91}$ Bank Markazi (n 90), Dissenting Opinion of Roberts CJ, joined by Sotomayor J, 1336.

${ }^{92}$ JVTA (n 77), Section 4(5).

${ }^{93}$ Tracy $v$ The Iranian Ministry of Information and Security, 2016 ONSC 3759 (Ontario Superior Court of Justice, 9 June 2016), affirmed 2017 ONCA 549 (Court of Appeal for Ontario, 30 June 2017). On 15 March 2018, the Supreme Court of Canada dismissed an application for leave to appeal from the Court of Appeal decision. By contrast, and despite Sentenza 238/2014, the Italian Court of Cassation has refused to recognize US judicial decisions arising from the terrorism exception, see Judgment of 28 October 2015, No 21946/2015 (Flatow v Iran), and Judgment of 28 October 2015, No 21947/2015 (Eisenfeld v Iran). For a critical and paradoxical case report on the Flatow decision, see Thomas Weatherall, 'Flatow v Iran', American Journal of International Law 110 (2016), 540-547.

${ }^{94}$ ONSC, Tracy (n 93), paras 50, 127-157. Most recently, these alleged cultural centres have been sold for some CAN\$28 million and the proceeds have been distributed to several victims (or their heirs) of acts of terrorism sponsored by Iran. Iranian authorities have depicted such developments as a 'clear breach of the international law'; see Dominic Dudley, 'Iran Takes Aim at Canada over Property Seizures in Toronto and Ottawa', Forbes, (17 September 2019), available at https://www. forbes.com/sites/dominicdudley/2019/09/17/iran-canada-property-seizures/\#23c8fe251910.

${ }^{95}$ SIA (n 77), Sections 12(1) and (3), and 16.

${ }^{96}$ ONSC, Tracy (n 93), paras 127-129.

${ }^{97} \mathrm{Ibid}$, paras $150,155-156$.
} 
law ${ }^{98}$ was, however, deceiving, insofar as it was not supported by any meaningful discussion of the international instruments and practice covering mixed bank accounts or, generally, property fulfilling sovereign functions. The Canadian courts never mentioned the ICJ's Jurisdictional Immunities Judgment, and particularly not the section concerning the illegality of the Italian courts' grant of exequatur to the Greek decisions awarding damages and costs in the proceedings relating to the Distomo massacre. ${ }^{99}$

One of the latest chapters in American exceptionalism within the area of international immunities is the Justice Against Sponsors of Terrorism Act (JASTA), otherwise known informally as the '9/11 Victims Bill', a statute finally passed by the US Congress on 28 September 2016 when an earlier veto by President Obama was overridden. ${ }^{100}$ JASTA amends the US Foreign Sovereign Immunities Act (FSIA) by introducing a new Section 1605B, according to which a foreign state is not immune from the jurisdiction of US courts in compensation proceedings brought by US nationals for physical injury to person or property, or for death caused by (i) an act of international terrorism in the US, and (ii) a tortious act of the foreign state, regardless where the tort occurred. ${ }^{101}$ The amendment applies to any civil action 'arising out of an injury to a person, property, or business on or after September 11, 2001'. ${ }^{102}$ The chief reason behind the adoption of JASTA is clearly to dispose of the requirement in the existing terrorism exception that a foreign state be listed as a state sponsor of terrorism in order for compensation claims to be pursued against it for terrorist acts committed in the US, especially those that were planned and/or supported outside of US territory. Indeed, mass litigation against Saudi Arabia instigated by thousands of victims (individuals, businesses, and insurance companies) of 9/11 is currently unfolding before US courts. ${ }^{103}$ Similarly, the amendment circumvents the conditions for triggering the territorial tort exception of the FSIA, which is applicable to claims for personal injury, death, or damage to property in the US, but only if the tortious act of the defendant foreign state also occurred in the US, and provided that act did not arise from the exercise of a discretionary function. ${ }^{104}$

\footnotetext{
${ }^{98} \mathrm{ONSC}$, Tracy (n 93), para 157.

${ }^{99} \mathrm{ICJ}$, Jurisdictional Immunities (n 2), paras 121-133.

${ }^{100}$ This is the sole veto override experienced by Obama during his eight years of presidency. See Jennifer Steinhauer/Mark Mazzetti/Julie Hirschfeld Davis, 'Congress Votes to Override Obama Veto on 9/11 Victims Bill', New York Times (28 September 2016).

${ }^{101}$ FSIA (n 76), Section 1605B(b) and (c).

${ }^{102}$ Justice Against Sponsors of Terrorism Act (JASTA), 28 September 2016, Section 7.

${ }^{103}$ One such case is The Underwriting Members of Lloyd's Syndicate 53 et al v Kingdom of Saudi Arabia et al, Case No 17-02129 (District Court for the Southern District of New York [SDNY]). See Jonathan Stempel, 'Saudi Arabia Faces \$6 Billion U.S. Lawsuit by Sept. 11 Insurers', Reuters (24 March 2017).

${ }^{104}$ FSIA (n 76), Section 1605(a)(5). See especially, In re Terrorist Attacks on September 11, 2001, 538 F.3d 71 (2nd Cir, 14 August 2008) (involving Saudi Arabia); Doe v Bi Laden, 663 F.3d 64 (2nd Cir, 7 November 2011) (involving Afghanistan). For background, see Sean Hennessy, 'In re the Foreign Sovereign Immunities Act: How the 9/11 Litigation Shows the Shortcomings of FSIA as a Tool in the War on Global Terrorism', Georgetown Journal of International Law 42 (2011), 855-878.
} 
How do we make sense of this North American practice? How do we square the widespread convictions and certainties relating to immunity law as bolstered by the ICJ with it? Is it nothing else than (North) American extravagance? It must be pointed out that there are robust reasons why the legislation and practice at stake cannot be equated to lawful countermeasures. It is true that in the North American context, unlike the Italian situation, the actual denial of immunity would usually be conditional on a prior executive's determination of target states and that we would not, therefore, be here confronted with an instance of misconceived judicial countermeasures. It is thus tempting to interpret ${ }^{105}$ the North American practice in light of the law of countermeasures, and there can be no doubt that troops of American lawyers would be willing to mount a major defence on this basis within the Iran $v$ US case before the ICJ and/or similar future disputes. However, when one takes a closer look at that practice and reviews it against the notion and requirements of countermeasures, this view becomes untenable. ${ }^{106}$ For present purposes, two points would suffice. First, as JASTA shows, the necessity of a prior executive's determination of the commission or support of acts of terrorism by states that may be denied immunity (for example Saudi Arabia) is not an inflexible requirement of US practice. To the contrary, JASTA has been adopted by the US legislature despite strong opposition by the executive. This is an unorthodox and clumsy situation for the implementation of veritable countermeasures. Secondly, and more fundamentally, to the best of my knowledge there exist no statements or any other documentary evidence from the governments concerned characterizing the terrorism legislation and practice at stake as countermeasures, that is, as measures which would be in breach of international obligations on state immunity were they not taken in response to wrongful acts by the target states. Accordingly, this would be an unlikely instance of implicit countermeasures. In reality, the only reasonable inference is that, at best, the governments concerned might conceive of the practice in question in terms of acts of retorsion, namely, as unfriendly conduct withdrawing a privilege predominantly afforded as a matter of grace and comity, not out of respect for international legal obligations.

To be sure, if we stick to the wisdom and certainty allegedly emanating from the 2012 ICJ Judgment, there is no alternative to regarding the US and Canadian terrorism exceptions as internationally wrongful acts sic et simpliciter. It is another thing, though, to maintain that American immunity practice must be set aside as a

\footnotetext{
${ }^{105} \mathrm{See}$, eg, Andrea Gattini, 'The Dispute on Jurisdictional Immunities of the State before the ICJ: Is the Time Ripe for a Change of the Law?', Leiden Journal of International Law 24 (2011), 173-200, at 183; van Alebeek, 'Jurisdictional Immunities of the State' 2012 (n 5), 299.

${ }^{106}$ See the excellent study by Simone Vezzani, 'Sul diniego delle immunità dalla giurisdizione di cognizione ed esecutiva a titolo di contromisura', Rivista di diritto internazionale 97 (2014), 36-87, at 82. See also Patricia Tarre Moser, 'Non-Recognition of State Immunity as a Judicial Countermeasure to Jus Cogens Violations: The Human Rights Answer to the ICJ Decision on the Ferrini Case', Goettingen Journal of International Law 4 (2012), 809-852; Giegerich, 'The Holy See' 2015 (n 46), 67 (the latter author, however, seems to start from the flawed assumption that the relevant countermeasure would be the enactment of the legislation at stake in and of itself, rather than its actual application by the governments and courts of the respective states).
} 
whole and given no weight whatsoever when assessing the state of the law in this area. ${ }^{107}$ This is the radical stance taken by authors such as Thomas Giegerich. He states: 'The proper reaction of the international community to such instances of ignorance or disregard of international law is to ignore or disregard them when it comes to gathering evidence of the development of international law'. ${ }^{108}$ This sentence proves too much. First, the North American legislation and judicial decisions in question do represent state practice. Such practice may then be considered as irrelevant for the formation of customary exceptions to state immunity, as it is not grounded in international opinio iuris but in considerations of comity and political convenience. Yet, it provides evidence contrary to the existence of customary rules in the field of state immunity. As it apparently involves two states only, the same practice is currently insufficient to override the contrary position of the majority of states. But it remains chiefly significant because it comes from two major countries that have been fundamental for the definitive consolidation of restrictive immunity standards and whose courts (especially US courts) adjudge a massive volume of immunity cases.

At the very least, the North American terrorism exceptions are a powerful reminder of the persistent strains and paradoxes in the law of international immunities. They are a crucial component of dissident views from certain key states that challenge common legal assumptions and debunk the myth of the universal acceptance of the customary status of immunity rules.

\section{Conclusion}

At the time of writing, the prospect of legal peace between Germany and Italy in relation to the litigation of Nazi war crimes reignited in Italian courts in the wake of Sentenza 238/2014 seems distant and, most worryingly, is being ignored by the governments concerned. It is as if the governments were confident that time will pass by and sooner or later heal the wounds left open by the loopholes and gaps in the reparation regimes elaborated over the past 70 years, regimes that were specifically meant to reckon with WWII crimes. However, such a failure to convincingly address the outstanding compensation claims of IMIs and comparable victims of Nazi crimes may also increasingly come to be regarded as staining the reputation of Germany and Italy, two countries which are champions of European integration and supposed to be frontrunners in the global pursuit of peace, justice, and the rule of law.

This chapter has stigmatized the opaque conduct of the governments concerned in the aftermath of Sentenza 238/2014 and their dismissive attitude vis-à-vis meaningful negotiations, which would be conducive to a just compensatory arrangement and,

\footnotetext{
${ }^{107}$ This is largely what the ICJ has done in its 2012 Judgment; see Pavoni, 'An American Anomaly?' 2011 (n 65).

${ }^{108}$ Giegerich, 'The Holy See' 2015 (n 46), 69.
} 
ultimately, legal peace. It has underscored how useful lessons in this area come from a series of WWII reparations agreements that, from the 1990s, were stipulated between the US and a number of states (including Germany) in order to put a halt to an expanding array of judicial proceedings before US courts that were endangering those states' entitlement to immunity.

Pace the ICJ, there are continuing manifestations of US practice, and lately Canadian practice, which corroborate the view that immunity for acta iure imperii is not a universally shared, inflexible international law dogma, especially when effective remedies for the victims, other than suits in the forum state, are absent. Serious violations of international humanitarian and human rights law are exerting a sustained pressure on the law of international immunities. At the very least, history and precedent show that when such egregious breaches of international law are at stake the only way of appeasing turbulent domestic courts and achieving a sustainable legal peace is the setting up of fair and reasonable means of redress for uncompensated victims.

\section{References}

Alebeek, Rosanne van, 'Jurisdictional Immunities of the State (Germany $v$. Italy): On Right Outcomes and Wrong Terms', German Yearbook of International Law 55 (2012), 281-318

Bank, Roland, 'The New Programs for Payments to Victims of National Socialist Injustice', German Yearbook of International Law 44 (2001), 307-352

Bettauer, Ronald, 'A Measure of Justice for Uncompensated French Railroad Deportees during the Holocaust', ASIL Insights, (1 March 2016), available at https://www.asil.org/insights/volume/ 20/issue/5/measure-justice-uncompensated-french-railroad-deportees-during-holocaust

Bilsky, Leora, 'Transnational Holocaust Litigation', European Journal of International Law 23 (2012), 349-375

Bothe, Michael, 'Remedies of Victims of War Crimes and Crimes against Humanities: Some Critical Remarks on the ICJ's Judgment on the Jurisdictional Immunity of States', in Anne Peters/Evelyne Lagrange/Stefan Oeter/Christian Tomuschat (eds), Immunities in the Age of Global Constitutionalism (Leiden: Brill Nijhoff 2015), 99-115

Bothe, Michael, 'The Decision of the Italian Constitutional Court Concerning the Jurisdictional Immunities of Germany', Italian Yearbook of International Law 24 (2014), 25-35

Brown, Chester/Roger O'Keefe, 'Article 21', in Roger O'Keefe/Christian J Tams (eds), The United Nations Convention on Jurisdictional Immunities of States and Their Property: A Commentary (Oxford: OUP 2013), 334-347

Caplan, Lee M, 'State Immunity, Human Rights, and Jus Cogens: A Critique of the Normative Hierarchy Theory', American Journal of International Law 97 (2003), 741-781

Cassese, Sabino, Dentro la Corte: Diario di un giudice costituzionale (Bologna: il Mulino 2015)

Cataldi, Giuseppe, 'A Historic Decision of the Italian Constitutional Court on the Balance Between the Italian Legal Order's Fundamental Values and Customary International Law', Italian Yearbook of International Law 24 (2015), 37-52

Conforti, Benedetto, 'Il legislatore torna indietro di circa novant'anni: la nuova norma sull'esecuzione sui conti correnti di Stati stranieri', Rivista di diritto internazionale 98 (2015), 558-561

Conforti, Benedetto, 'The Judgment of the International Court of Justice on the Immunity of Foreign States: A Missed Opportunity’, Italian Yearbook of International Law 21 (2011), $133-142$ 
Daugirdas, Kristina/Julian D Mortenson, 'Contemporary Practice of the United States Relating to International Law', American Journal of International Law 110 (2016), 554-595

Eizenstat, Stuart, Imperfect Justice: Looted Assets, Slave Labor, and the Unfinished Business of World War II (New York: Public Affairs 2004)

Finke, Jasper, 'Sovereign Immunity: Rule, Comity or Something Else?', European Journal of International Law 21 (2010), 853-881

Focarelli, Carlo, Diritto internazionale (Padua: Cedam $4^{\text {th }}$ ed 2017)

Forlati, Serena, 'Judicial Decisions, Immunities of Foreign States from Jurisdiction', Italian Yearbook of International Law 25 (2015), 497-509

Franceschelli, Ferdinando, 'Germany Held Responsible for the Nazi Massacre of Pietransieri', Italian Yearbook of International Law 27 (2017), 449-452

Francioni, Francesco, 'Access to Justice and Its Pitfalls: Reparation for War Crimes and the Italian Constitutional Court', Journal of International Criminal Justice 14 (2016), 629-636

Frulli, Micaela, "'Time Will Tell Who Just Fell and Who's Left Behind": On the Clash between the International Court of Justice and the Italian Constitutional Court', Journal of International Criminal Justice 14 (2016), 587-594

Gattini, Andrea, 'The Dispute on Jurisdictional Immunities of the State before the ICJ: Is the Time Ripe for a Change of the Law?', Leiden Journal of International Law 24 (2011), 173-200

Giegerich, Thomas, 'The Holy See, a Former Somalian Prime Minister, and a Confiscated Pissarro Painting: Recent US Case Law on Foreign Sovereign Immunity', in Anne Peters/Evelyne Lagrange/Stefan Oeter/Christian Tomuschat (eds), Immunities in the Age of Global Constitutionalism (Leiden: Brill Nijhoff 2015), 51-69

Hennessy, Sean, 'In re the Foreign Sovereign Immunities Act: How the 9/11 Litigation Shows the Shortcomings of FSIA as a Tool in the War on Global Terrorism', Georgetown Journal of International Law 42 (2011), 855-878

Luzzatto, Riccardo, 'La giurisdizione sugli Stati stranieri tra Convenzione di New York, norme internazionali generali e diritto interno', Comunicazioni e studi 23 (2007), 1-21

Palchetti, Paolo, "A key institution for interpreting international law and guaranteeing global compliance with its provisions": la dichiarazione italiana di accettazione della competenza della Corte internazionale di giustizia', Rivista di diritto internazionale 98 (2015), 114-125

Pavoni, Riccardo, 'An American Anomaly? On the ICJ's Selective Reading of United States Practice in Jurisdictional Immunities of the State', Italian Yearbook of International Law 21 (2011), 143-159

Pavoni, Riccardo, 'How Broad is the Principle Upheld by the Italian Constitutional Court in Judgment No. 238?', Journal of International Criminal Justice 14 (2016), 573-585

Pavoni, Riccardo, 'Human Rights and the Immunities of Foreign States and International Organizations', in Erika de Wet/Jure Vidmar (eds), Hierarchy in International Law: The Place of Human Rights (Oxford: OUP 2012), 71-113

Peters, Anne, 'Immune against Constitutionalisation?', in Anne Peters/Evelyne Lagrange/Stefan Oeter/Christian Tomuschat (eds), Immunities in the Age of Global Constitutionalism (Leiden: Brill Nijhoff 2015), 1-19

Peters, Anne, 'Let Not Triepel Triumph-How To Make the Best Out of Sentenza No. 238 of the Italian Constitutional Court for a Global Legal Order', EJIL:Talk!, (22 December 2014), available at www.ejiltalk.org/let-not-triepel-triumph-how-to-make-the-best-out-of-sentenzano-238-of-the-italian-constitutional-court-for-a-global-legal-order-part-i

Pisillo Mazzeschi, Riccardo, 'Access to Justice in Constitutional and International Law: The Recent Judgment of the Italian Constitutional Court', Italian Yearbook of International Law 24 (2014), $7-23$

Steinhauer, Jennifer/Mark Mazzetti/Julie Hirschfeld Davis, 'Congress Votes to Override Obama Veto on 9/11 Victims Bill', New York Times (28 September 2016)

Stempel, Jonathan, 'Saudi Arabia Faces \$6 Billion U.S. Lawsuit by Sept. 11 Insurers', Reuters (24 March 2017) 
Tarre Moser, Patricia, 'Non-Recognition of State Immunity as a Judicial Countermeasure to Jus Cogens Violations: The Human Rights Answer to the ICJ Decision on the Ferrini Case', Goettingen Journal of International Law 4 (2012), 809-852

Tomuschat, Christian, 'The Case of Germany v. Italy before the ICJ', in Anne Peters/Evelyne Lagrange/Stefan Oeter/Christian Tomuschat (eds), Immunities in the Age of Global Constitutionalism (Leiden: Brill Nijhoff 2015), 87-98

Tomuschat, Christian, 'The National Constitution Trumps International Law', Italian Journal of Public Law 6 (2014), 189-196

Vezzani, Simone, 'Sul diniego delle immunità dalla giurisdizione di cognizione ed esecutiva a titolo di contromisura', Rivista di diritto internazionale 97 (2014), 36-87

Weatherall, Thomas, 'Flatow v Iran', American Journal of International Law 110 (2016), 540-547

Open Access This chapter is licensed under the terms of the Creative Commons Attribution 4.0 International License (http://creativecommons.org/licenses/by/4.0/), which permits use, sharing, adaptation, distribution and reproduction in any medium or format, as long as you give appropriate credit to the original author(s) and the source, provide a link to the Creative Commons license and indicate if changes were made.

The images or other third party material in this chapter are included in the chapter's Creative Commons license, unless indicated otherwise in a credit line to the material. If material is not included in the chapter's Creative Commons license and your intended use is not permitted by statutory regulation or exceeds the permitted use, you will need to obtain permission directly from the copyright holder.

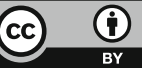

